\title{
Biochemical alterations in native and exotic oyster species in Brazil in response to increasing temperature
}

\author{
Anthony Moreira ${ }^{\text {a }}$, Etelvina Figueira ${ }^{\text {a }}$, Iracy L. Pecora ${ }^{\text {b }}$, Amadeu M.V.M. Soares ${ }^{\text {a }}$, Rosa Freitas ${ }^{\text {a,* }}$ \\ a Departmento de Biologia \&' CESAM, Universidade de Aveiro, Campus Universitário de Santiago, 3810-193 Aveiro, Portugal

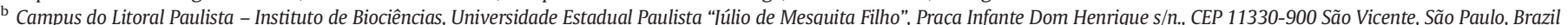

\section{A R T I C L E I N F O}

\section{Article history:}

Received 25 July 2016

Received in revised form 21 October 2016

Accepted 25 October 2016

Available online 3 November 2016

\section{Keywords:}

Crassostrea brasiliana

Crassostrea gigas

Temperature

Oxidative stress

Metabolism

Native

Introduced

\begin{abstract}
A B S T R A C T
The increase of temperature in marine coastal ecosystems due to atmospheric greenhouse gas emissions is becoming an increasing threat for biodiversity worldwide, and may affect organisms' biochemical performance, often resulting in biogeographical shifts of species distribution. At the same time, the introduction of nonnative species into aquatic systems also threatens biodiversity and ecosystem functions. Oysters are among the most valuable socio economic group of bivalve species in global fishery landings, and also provide numerous ecosystem services. However, the introduction of non-native oyster species, namely Crassostrea gigas for aquaculture purposes may threaten native oyster species, mainly by out competing their native congeners. It is therefore of upmost importance to understand physiological and biochemical responses of native and introduced oyster species in a scenario of global temperature rise, in order to provide knowledge that may allow for better species management. Hence, we compared biochemical alterations of the introduced C. gigas and the native Crassostrea brasiliana, the most important oyster species in Brazil, in response to different thermal regimes for 28 days $\left(24,28\right.$ and $32{ }^{\circ} \mathrm{C}$ ). For this, metabolism (ETS), energy content (GLY), antioxidant system (SOD, CAT and GSH/ GSSG) and cellular damage (LPO) were assessed in adult and juvenile specimens of both species. Juvenile C. gigas were the most affected by increased temperatures, presenting higher mortality, more pronounced antioxidant response (SOD), whereas adults were more tolerant than juveniles, showing no mortality, no significant changes in antioxidant enzymes activity neither energy expenditure. Native $C$. brasiliana juveniles presented lower mortality and less pronounced biochemical alterations were noted at higher temperature comparing to non-native $C$. gigas juveniles. Adult $C$. brasiliana were the least responsive to tested temperatures. Results obtained in this study bring interesting new insights on different oyster species life stages' physiological and biochemical tolerance towards thermal stress. The native species $C$. brasiliana showed ability to maintain biochemical performance at higher temperatures, with less pronounced biochemical changes than the non-native species. The introduced ( $C$. gigas) showed to be more sensitive, presenting biochemical alterations to cope with the increase of temperature. Despite the lower observed fitness of the introduced species to temperatures closer to those naturally experienced by the native species, the ability of $C$. gigas to cope with higher temperatures should still raise concerns towards the native species $C$. brasiliana management and protection.
\end{abstract}

(c) 2016 Elsevier Inc. All rights reserved.

\section{Introduction}

Rising anthropogenic greenhouse gas emissions have proven to lead to unprecedented oscillations in temperature regimes in several terrestrial and marine ecosystems (Greco et al., 2011; IPCC, 2013). Low lying coastal marine ecosystems such as mangroves and estuaries are particularly vulnerable to global warming, given that they are naturally subjected to high temperature fluctuation (Harley et al., 2006). Projections for temperature rise by the end of the 21st century of between 2 and $4{ }^{\circ} \mathrm{C}$

\footnotetext{
* Corresponding author at: Departamento de Biologia, Universidade de Aveiro, Campus Universitário de Santiago, 3810-193 Aveiro, Portugal.

E-mail addresses: Anthony.moreira@ua.pt (A. Moreira), rosafreitas@ua.pt (R. Freitas).
}

(Hansen et al., 2013; IPCC, 2013; Solomon, 2007) and 2.4 to $6.4{ }^{\circ} \mathrm{C}$ (Smith et al., 2009), are of particular concern regarding the impacts on aquatic ecosystems biodiversity and functions (Brierley and Kingsford, 2009; Doney et al., 2012). In particular, temperature is considered to be the key factor determining biogeographical patterns, with intertidal ecosystems showing to be particularly susceptible to pronounced and rapid changes (Somero, 2012). Studies have pointed out several consequences of increasing temperature at biological levels, such as changes in reproduction timing and success, growth performance, species mortality and shifts on species geographical distribution (Cheung et al., 2009; Smolders et al., 2004; Talmage and Gobler, 2011).

In addition to global warming due to anthropogenic activities, the introduction of exotic species is another important factor threatening 
biodiversity worldwide (Hansen et al., 2013; Occhipinti-Ambrogi, 2007). In this respect, bivalves are among the most invading faunal groups (Francis, 2012), and the impacts due to their introduction, mainly for aquaculture purposes, have been a topic of concern (Mckindsey et al., 2007). Several biological characteristics of introduced bivalve species, often inherent to their aquaculture interest, such as high growth rates, adaptability to a wide range of environmental conditions, tolerance to physiological stress and high fertility, enable for their establishment and posterior expansion into new environments, and consequent dominance over native species. Other impacts of introducing nonnative bivalve species can include alterations on ecosystem functioning (e.g. Kerckhof et al., 2007), introduction of pathogenic agents (e.g. Grizel and Héral, 1991), and deleterious interactions with other organisms (e.g. Diederich et al., 2005).

Among non-native bivalve species, oysters are one of the most invading groups and in addition to their ecological importance (Coen et al., 2007; Grabowski et al., 2012), they also represent major socio economic resources, and are among the most important group of mollusc species in global aquaculture landings (FAO, 2012). In fact, as a result of the increase of shellfish demand, non-native oyster species have been successfully introduced in a number of countries in an attempt to enhance production (Carranza et al., 2009). Presently, the most important cultured species Crassostrea gigas has been successfully introduced into aquaculture systems worldwide (Miossec et al., 2009). The introduction of this species may however threaten native oyster species given its potential to become invasive, as proven in several countries (Ruesink et al., 2005). The introduction of exotic oyster species can cause deleterious impacts on native oyster populations by introducing pathogenic agents and consequent mortality events (Ruesink et al., 2005; Mckindsey et al., 2007) and by outcompeting of native oyster species (Krassoi et al., 2008). In Brazil, C. gigas seeds are currently produced and grown in the southern state of Santa Catarina (Melo et al., 2010), while native oyster species are mainly extracted from natural environments, from which Crassostrea brasiliana presents higher economic and zootechnical yield (Mendonça and Machado, 2010; Neto et al., 2013). The introduction of $C$. gigas in Brazil has become particularly concerning, especially since the natural occurrence of this species has already been reported (de Melo et al., 2010; Pie et al., 2006).

In light of this, the study of differences in performance between native and non-native species, in a scenario of global temperature rise if of upmost importance in order to better understand the underlying tolerance mechanisms that enable species to survive and compete in a changing environment (Parker et al., 2013; Somero, 2010). Therefore, the present study aimed to assess the biochemical responses of the native $C$. brasiliana and the introduced $C$. gigas oyster species to increasing water temperatures, in both juvenile and adult specimens, by use of a set of biomarkers (metabolism, energetic reserves, antioxidant capacity and membrane damage). A comparative analysis between different species and different life stages responses was conducted. The Pacific oyster $C$. gigas is the most important oyster species produced in aquaculture systems, providing annual global landings exceeding 40 million tonnes (Miossec et al., 2009). The mangrove oyster C. brasiliana is the most important native oyster species in Brazilian coastal waters, and is mainly extracted from the natural environment (Gomes et al., 2014). The most productive C. brasiliana natural banks are located in the southern coast of Brazil, in the Cananéia estuary (Galvão et al., 2013; Ristori et al., 2007). This mangrove dominated ecosystem is internationally recognized as one of the most productive ecosystems of the South Atlantic, having been declared Natural Heritage Site for knowledge and conservation of human values based on sustainable development standards, and included in the Atlantic Forest Biosphere by UNESCO in 1999 and 2005 respectively. In this mangrove dominated ecosystem the native oyster is one of the main fishery resources for the local communities, representing an important socio economic resource (Mendonça and Machado, 2010).

\section{Material and methods}

\subsection{Species collection and experimental setup}

Crassostrea brasiliana specimens used in the present study were collected in submerged oyster beds $\left(25^{\circ} 00^{\prime} 29.50^{\prime \prime} \mathrm{S} 48^{\circ} 01^{\prime} 29.35^{\prime \prime} \mathrm{W}\right)$ from a local exploration in the Mandira Extractive Reserve in the Cananéia estuary (Brazil). In this system, mean annual temperature is $23.9^{\circ} \mathrm{C}$, varying between 20 and $28^{\circ} \mathrm{C}$, depending on season (Schaeffer-Novelli et al., 1990). Similar sized oysters were selected for laboratory exposures, from both adult ( $7.1 \pm 0.6 \mathrm{~cm}$ length; $5.8 \pm 0.4 \mathrm{~cm}$ width), and juvenile ( $3.9 \pm 1.1 \mathrm{~cm}$ length; $2.4 \pm 0.6 \mathrm{~cm}$ width) specimens. Crassostrea gigas were obtained from the Laboratory of Marine Molluscs of the University of Santa Catarina (Brazil). Seawater temperature in Santa Catarina varies between 16.1 and $26.6{ }^{\circ} \mathrm{C}$ (Gomes et al., 2014). Juvenile oysters ( $4.5 \pm 0.2 \mathrm{~cm}$ length; $2.5 \pm 0.1 \mathrm{~cm}$ width), and adults $(7.7 \pm 0.4 \mathrm{~cm}$ length; $5.5 \pm 0.3 \mathrm{~cm}$ width) were selected.

Ten individuals from each species batch were used to confirm species phylogenetic lineage through molecular analysis.

Species collection and experimental assays took place during April and May 2015, and were performed in separate for each species. After collection, oysters were acclimated to laboratory conditions during one week prior to the beginning of exposure to three different temperature levels. During this period, juvenile and adult specimens were maintained in separate tanks, in aerated artificial seawater (Ocean Fish - Prodac) (Temperature $24{ }^{\circ} \mathrm{C}$, Salinity 29) and daily fed with AlgaMac Protein Plus (initial cell density of $10^{9}$ cells per $\mathrm{L}^{-1}$ ). After one-week acclimation, oysters were randomly distributed into testing chambers, consisting of $10 \mathrm{~L}$ tanks with individual air flow biological filters. Juveniles and adults were maintained in separate, with 4 juveniles and 2 adults per chamber. Three different temperature regimes were tested $\left(24,28\right.$ and $\left.32{ }^{\circ} \mathrm{C}\right)$, for both juvenile and adults, with 3 replicated tanks per temperature. Temperature levels were chosen as present average temperature $\left(24^{\circ} \mathrm{C}\right)$, maximum temperature $\left(28{ }^{\circ} \mathrm{C}\right)$ at the Cananéia estuary, and $32^{\circ} \mathrm{C}$ for predicted increase of global surface temperature for the end of the 21st century of $4{ }^{\circ} \mathrm{C}$ (Solomon, 2007). Temperature was reached using thermostats in water baths surrounding each group of chambers. To achieve increased temperature exposures (28 and $32{ }^{\circ} \mathrm{C}$ ), $1{ }^{\circ} \mathrm{C}$ was increased per day from the initial acclimation temperature $\left(24^{\circ} \mathrm{C}\right)$, until the chosen testing values were reached in all testing groups, thus finalizing the acclimation period.

After this period, exposures to different temperatures were conducted during 28 days. Water parameters (Temperature, dissolved oxygen, salinity), were daily monitored (YSI Pro plus) and corrected whenever necessary. Chambers were daily checked for mortality. Faecal debris were removed prior to feeding (AlgaMac Protein Plus) 5 days a week, giving partial water renewals of approximately $10 \%$. Total water renewals were performed weekly. At the end of the experiment (28 days), oysters were frozen at $-80{ }^{\circ} \mathrm{C}$ until further analysis.

\subsection{Species confirmation through COI analysis}

Species phylogenetic lineages were confirmed by analysis of the $\mathrm{Cy}$ tochrome oxidase subunit I gene sequence (COI), in ten individuals from each species batch. Genomic DNA extractions were made with NZY Tissue gDNA Isolation Kit (NZYTech) using oysters' adductor muscle. $C$. brasiliana COI was amplified with primers and amplification cycles described in de Melo et al. (2010). C. gigas COI was amplified with primers by Folmer et al. (1994) and amplification cycles described in Reece et al. (2008). Nucleotide sequencing of each purified Polymerase Chain Reaction (PCR) product was commercially performed by STABvida (Portugal). The obtained sequences were compared to a set of C. brasiliana, C. rhizophorae and C. gigas sequences deposited on GenBank. Blast and multiple alignments of sense and antisense sequences were conducted with MEGA v6, using default alignment settings of the CLUSTALW algorithm (Tamura et al., 2013). Phylogenetic 
relationships were calculated by Maximum likelihood (ML) reconstruction method (Jukes-Cantor model), with MEGA v6 software. Node support was assessed by 1000 bootstrap values replicates.

\subsection{Biochemical analysis}

For biochemical analysis, each oyster was individually and manually homogenized with a mortar and a pestle under liquid nitrogen. Homogenates from each specimen were further separated into aliquots to perform individual extractions using specific buffers for each parameter. Buffers were added to aliquots in a 2:1 volume ratio, and the mixture sonicated for $15 \mathrm{~s}\left(55 \mathrm{~W} \cdot \mathrm{cm}^{-2}\right.$ at $\left.4{ }^{\circ} \mathrm{C}\right)$, and posteriorly centrifuged for $15 \mathrm{~min}\left(10,000 \mathrm{~g}\right.$ at $\left.4{ }^{\circ} \mathrm{C}\right)$. Supernatants were stored at $-80^{\circ} \mathrm{C}$ or directly used to measure: i) electron transport system (ETS) activity; ii) glycogen (GLY) content; iii) Superoxide dismutase (SOD) and Catalase (CAT) enzymatic activities; iv) reduced (GSH) to oxidized glutathione (GSSG) ratio (GSH/GSSG); v) lipid peroxidation (LPO) levels.

\subsubsection{Metabolism}

ETS activity was measured according to King and Packard (1975) and modifications introduced by (De Coen and Janssen (1997). Extractions were made in Tris- $\mathrm{HCl}(0.1 \mathrm{M})$ buffer $(\mathrm{pH} 8.5,15 \%(w / v)$ PVP, $153 \mathrm{mM}$ magnesium sulfate $\left(\mathrm{MgSO}_{4}\right)$ and $0.2 \%$ (v/v) Triton X-100). Reaction was made in $0.13 \mathrm{M}$ Tris-HCL buffer ( $\mathrm{pH} 8.5,0.3 \%$ (v/v) Triton X100), $0.25 \mathrm{mM}$ NADH, $36.5 \mu \mathrm{M}$ NADPH, and $2.3 \mathrm{mM}$ INT. Absorbance was measured at $490 \mathrm{~nm}$ every $25 \mathrm{~s}$ during $10 \mathrm{~min}$. The amount of formazan produced was determined using $\varepsilon=15,900 \mathrm{M}^{-1} \mathrm{~cm}^{-1}$ and results expressed in $\mathrm{nmol} \cdot \mathrm{min}^{-1} \cdot \mathrm{mg}^{-1}$ protein. Protein was quantified following (Robinson and Hogden, 1940), using bovine serum albumin (BSA) as standards.

\subsubsection{Energy reserves}

GLY content was determined following Yoshikawa (1959). Extractions were performed with sodium phosphate buffer ( $50 \mathrm{mM}$ sodium dihydrogen phosphate monohydrate; $50 \mathrm{mM}$ disodium hydrogen phosphate dehydrate ( $\mathrm{pH} \mathrm{7.0);} 1 \mathrm{mM}$ ethylenediamine tetraacetic acid disodium salt dihydrate (EDTA); $1 \%(\mathrm{v} / \mathrm{v}$ ) Triton X-100; $1 \%(\mathrm{v} / \mathrm{v})$ polyvinylpyrrolidone (PVP); $1 \mathrm{mM}$ dithiothreitol (DTT)). Glucose standards were used to obtain a calibration curve $\left(0\right.$ to $5 \mathrm{mg} \cdot \mathrm{mL}^{-1}$ ). Samples were incubated at room temperature for $30 \mathrm{~min}$ and absorbance measured at $492 \mathrm{~nm}$. GLY content was expressed in $\mathrm{mg} \cdot \mathrm{g}^{-1}$ fresh weight (FW).

\subsubsection{Antioxidant system}

For SOD and CAT activity measurements, extractions were performed in sodium phosphate buffer previously described. SOD activity was quantified following Beauchamp and Fridovich (1971), using SOD standards $0.25-60 \mathrm{U} \cdot \mathrm{mL}^{-1}$. Reaction was made in phosphate buffer $50 \mathrm{mM}$ (pH 8.0), 68.4 $\mu \mathrm{M}$ NBT, 0.1 mM DTPA, 0.1 mM hypoxanthine. Enzyme activity was measured at $560 \mathrm{~nm}$ in a microplate reader after adding xanthine oxidase at $5 \mathrm{mU}$, diluted in phosphate buffer $50 \mathrm{mM}$ (pH 8.0). Absorbance was read after $20 \mathrm{~min}$ incubation at $22{ }^{\circ} \mathrm{C}$, and the rate of nitroblue tetrazolium (NBT) reduction calculated. SOD activity was expressed in $\mathrm{U} \cdot \mathrm{mg}^{-1}$ protein $\left(\mathrm{U}=\mu \mathrm{mol} \cdot \mathrm{min}^{-1}\right)$.

CAT activity was determined according to Johansson and Borg (1988) at room temperature $\left(22^{\circ} \mathrm{C}\right)$. A standard curve was determined using formaldehyde standards $(0-150 \mu \mathrm{M})$. Reaction was made in phosphate buffer ( $\mathrm{pH} 7.0$ ), 5.6 M Methanol, and the presence of $35.28 \mathrm{mM}$ $\mathrm{H}_{2} \mathrm{O}_{2}$. Reaction was stopped by adding $10 \mathrm{M} \mathrm{KOH}$ and $34.2 \mathrm{mM}$ purpald. Absorbance was measured at $540 \mathrm{~nm}$ in a microplate reader. CAT activity was expressed in $\mathrm{U} \cdot \mathrm{mg}^{-1}$ protein $\left(\mathrm{U}=\mathrm{nmol} \cdot \mathrm{min}^{-1}\right)$.

GSH and GSSG concentrations were determined spectrophotometrically following Rahman et al. (2007). Extraction buffer consisted of 0.6\% sulfosalicylic acid in potassium phosphate buffer ( $0.1 \mathrm{M}$ dipotassium phosphate, $0.1 \mathrm{M}$ potassium dihydrogen phosphate, $5 \mathrm{mM}$ EDTA, $0.1 \%$ Triton X-100, pH 7.5). Reduced and oxidized glutathione standards were used for GSH and GSSG quantifications separately (0$\left.60 \mu \mathrm{mol} \cdot \mathrm{L}^{-1}\right)$. Absorbance was measured at $412 \mathrm{~nm}$, and GSH and GSSG concentrations were determined in $\mathrm{nmol} \cdot \mathrm{mg}^{-1}$ protein, and further expressed as a ratio (GSH/GSSG), determined taking in account the number of thiol equivalents (GSH/2* GSSG).

\subsubsection{Membrane damage}

LPO levels were quantified according to Ohkawa et al. (1979). Supernatants were extracted in $20 \%(\mathrm{v} / \mathrm{v})$ trichloroacetic acid (TCA). Absorbance was measured at $535 \mathrm{~nm}\left(\varepsilon=156 \mathrm{mM}^{-1} \mathrm{~cm}^{-1}\right)$. LPO levels were expressed in nmol MDA.g ${ }^{-1} \mathrm{FW}$.

\subsection{Biochemical data analysis}

Biochemical parameters (ETS, GLY, SOD, CAT, GSH/GSSG and LPO) were submitted to hypothesis testing using permutational analysis of variance, employing the PERMANOVA + add-on in PRIMER v6 (Anderson et al., 2008).

Parameters were analyzed following a one-way hierarchical design, with temperature condition for either juvenile or adult oyster species as the main fixed factor. Concerning each descriptor, null hypothesis tested were: $\mathrm{H}_{0}{ }^{\prime}$ ) for each species and each life stage (juvenile or adult), no significant differences existed among temperature levels; $\mathrm{H}_{0}{ }^{\prime \prime}$ ) for each temperature level, and for each species no significant differences existed between life stages; $\left.\mathrm{H}_{0}{ }^{\prime \prime \prime}\right)$ for each life stage at each temperature level, no significant differences existed between species. Differences were considered significant for $p \leq 0.05$, and were represented in figures with different letters (minuscule for juvenile, and majuscule for adult specimens). At each temperature, significant differences between juvenile and adult oysters of each species were represented with an asterisk. Monte-Carlo $p$-values from each biomarker comparison between species were presented in Table I.

\section{Results and discussion}

\subsection{COI gene molecular analysis}

Analyzed COI sequences from each batch of oysters allowed for a clear separation of both species, and to further classify each batch as belonging to $C$. gigas and C. brasiliana (Fig. 1). Maximum likelihood (ML) reconstructions method provided $100 \%$ bootstrap support separation for each species, $C$. gigas and $C$. brasiliana samples clustered with deposited GenBank sequences of each species in separate (Fig. 1).

\subsection{Mortality}

In the present study mortality was only registered in juvenile oysters of both species. C. brasiliana juveniles presented $33 \%$ mortality at $28{ }^{\circ} \mathrm{C}$ and $25 \%$ at $32{ }^{\circ} \mathrm{C}$, and no mortality at the lowest temperature $24^{\circ} \mathrm{C}$. Higher mortality was observed for $C$. gigas juveniles exposed to the highest temperature $\left(32^{\circ} \mathrm{C}\right)$, reaching $67 \%$, while no mortality was observed at 24 and $28{ }^{\circ} \mathrm{C}$. C. gigas juveniles that survived at $32{ }^{\circ} \mathrm{C}$ were therefore removed from further analysis in order not to introduce a biased effect of selecting the most resistant individuals on results.

\subsection{Metabolism}

The ETS activity has successfully been used as a measure of metabolic potential in different organisms (Berridge et al., 2005), including the assessment of the effects of environmental factors such as anoxia, temperature, salinity and pollutants in bivalve species (Almeida et al., 2014; Le Moullac et al., 2007; Moreira et al., 2016). In fact temperature is one of the factors that most influences organisms ETS activity (Devol and Packard, 1978; Fanslow et al., 2001; Nalepa et al., 2010; Simčič and Brancelj, 2004), and can reflect species thermal tolerance (Packard 
Table I

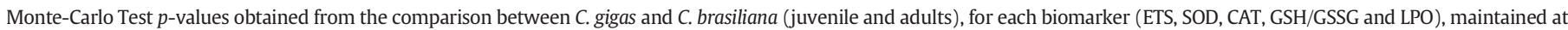
temperatures 24,28 and $32{ }^{\circ} \mathrm{C}$. Statistically significant values between species, in juvenile and adult specimens, for each condition, are highlighted in bold ( $p$-values $\leq 0.05$ ).

\begin{tabular}{|c|c|c|c|c|c|c|c|c|}
\hline & & Temp. & ETS & GLY & SOD & CAT & GSH/GSSG & LPO \\
\hline \multirow[t]{3}{*}{ Juvenile } & C. gigas vs. C. brasiliana & $24^{\circ} \mathrm{C}$ & 0.0001 & 0.4012 & 0.5498 & 0.3286 & 0.2907 & 0.0004 \\
\hline & & $28{ }^{\circ} \mathrm{C}$ & 0.0038 & 0.0001 & 0.001 & 0.4279 & 0.5171 & 0.0002 \\
\hline & & $32{ }^{\circ} \mathrm{C}$ & - & - & - & - & - & - \\
\hline \multirow[t]{3}{*}{ Adult } & C. gigas vs. C. brasiliana & $24{ }^{\circ} \mathrm{C}$ & 0.0001 & 0.0006 & 0.0312 & 0.5522 & 0.2461 & 0.0137 \\
\hline & & $28{ }^{\circ} \mathrm{C}$ & 0.0001 & 0.0039 & 0.4094 & 0,0282 & 0.2660 & 0.0031 \\
\hline & & $32{ }^{\circ} \mathrm{C}$ & 0.0001 & 0.0064 & 0.2893 & 0.9338 & 0.0006 & 0.7624 \\
\hline
\end{tabular}

et al., 1975; Simčič and Brancelj, 2004). Ectothermic organisms hold adaptive mechanisms to enhance metabolic efficiency in a wide range of temperatures in order to maintain energetic homeostasis (Packard et al., 1975).

Results for ETS in C. gigas are presented in Fig. 2A. Juveniles presented no significant differences in ETS activity between 24 and $28^{\circ} \mathrm{C}$. Adults presented significantly higher ETS activity at $28^{\circ} \mathrm{C}$ comparing to the lowest temperature $\left(24^{\circ} \mathrm{C}\right)$, and an intermediate yet not significantly different, ETS activity at $32^{\circ} \mathrm{C}$. Juveniles presented significantly higher ETS activity than adults at 24 and $28{ }^{\circ} \mathrm{C}$ (Fig. 2A). Higher ETS activities observed in juveniles, could be related to higher metabolic demand by growing individuals, since oxygen requirements and protein turnover rates are generally higher per unit of weight in younger organisms (Hawkins, 1995). These results could relate to Lejart et al. (2011) studies on C. gigas from the environment, that observed that juvenile $C$. gigas present consistently higher respiration rates than adults throughout the year. In the same study, juvenile oysters presented no seasonal variation in respiration rates in contrast to adults, that presented significant increases of respiration rates, related to seasonal increases of temperature
(Lejart et al., 2011). The increase of ETS activity in adults indicates an increase of active ETS enzyme concentrations in response to higher temperature $\left(28^{\circ} \mathrm{C}\right)$. It is generally accepted that in the absence of other limiting factors, increasing temperature induces higher metabolic rates (Angilletta, 2009; Pörtner et al., 2006). Le Moullac et al. (2007) observed increased ETS activity with increasing temperature in $C$. gigas adults, although testing a temperature range of 12,15 and $20^{\circ} \mathrm{C}$. Assuming these authors results, and those observed in the present study (increased ETS activity from 24 to $28{ }^{\circ} \mathrm{C}$ ), we suggest that $C$. gigas adults can increase the concentrations of active ETS units in response to increasing temperature up to a certain threshold. Increasing the number of rate limiting enzymes to sustain aerobic metabolism (as proposed here for ETS) has been shown in mussel Modiolus modiolus, although during acclimation to cold temperatures, namely aerobic enzymes citrate synthase and cytochrome oxidase (Lesser and Kruse, 2004). Other examples of these adaptation mechanisms include studies on the copepod Acartia tonsa, that showed increased activity of ETS with the increase of temperature from 17 to 21 or $29{ }^{\circ} \mathrm{C}$, leading the author to conclude that higher concentrations of rate limiting enzymes were

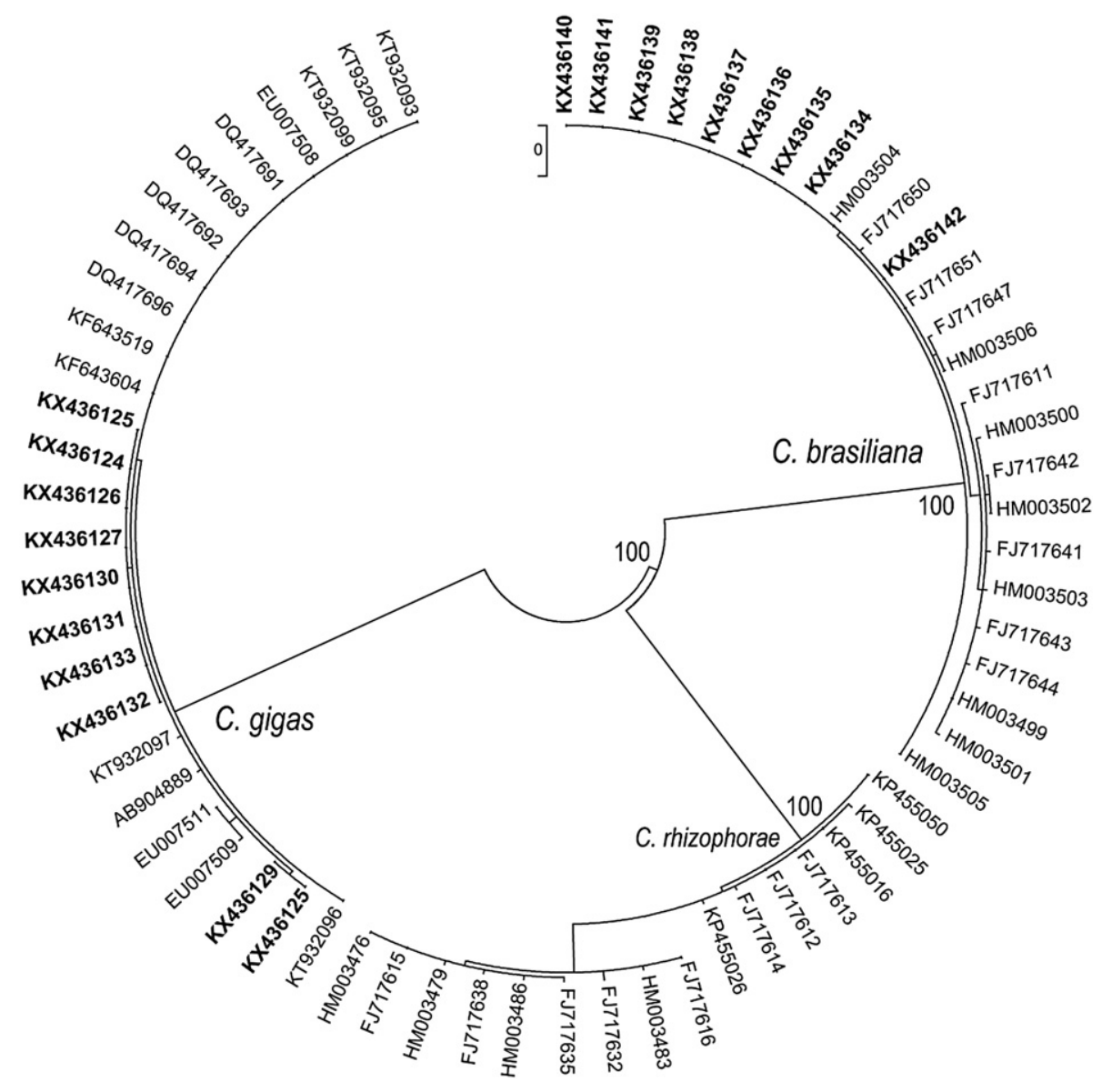

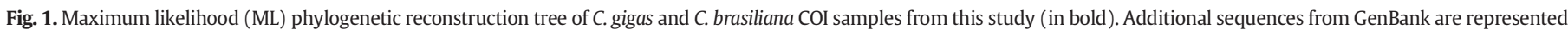
by their accession numbers. A set of $C$. rhizophorae GenBank accession numbers are inserted as outgroup. Clade separation nodes supported by $100 \%$ bootstrap values are indicated. 


\section{Juvenile adult}

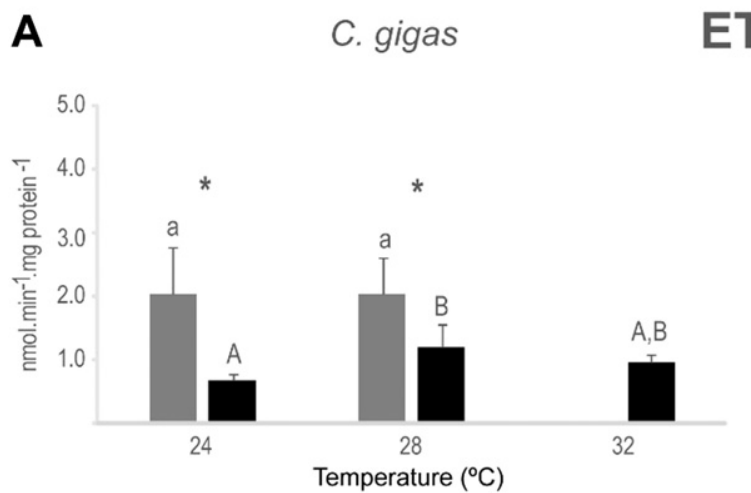

ETS

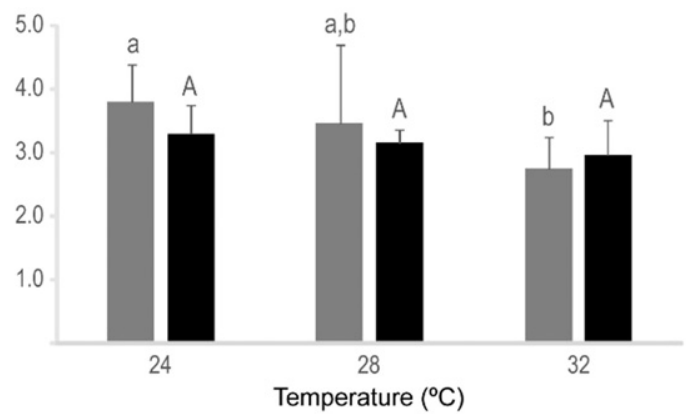

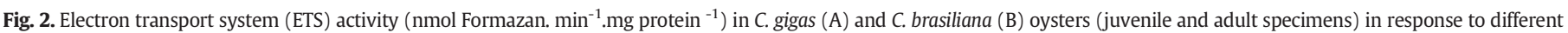

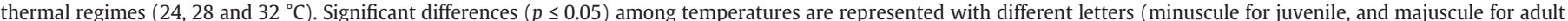

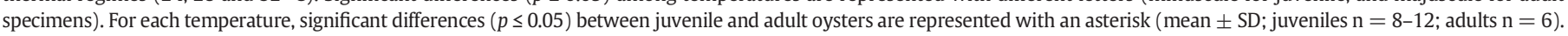

present at higher temperatures (Båmstedt, 1980). The ETS of zebra mussel Dreissena polymorpha in the environment also presented different activity levels depending on season and site location, with higher activities observed during late spring (Fanslow et al., 2001). No further increase of ETS activity at the highest temperature may indicate enzymatic inactivation or denaturation, when temperature is beyond that of the species natural temperature range (Yurista, 1999), possibly indicating the upper thermal limit of $C$. gigas adults was reached between 28 and $32{ }^{\circ} \mathrm{C}$.

Regarding $C$. brasiliana, the ETS activity of juveniles presented a decreasing trend in activity with the increase of temperature, with significantly higher ETS activity in juveniles at $24{ }^{\circ} \mathrm{C}$ compared to that observed at $32{ }^{\circ} \mathrm{C}$. Adults presented no significant differences in the ETS activity among temperatures. No significant differences were observed between juvenile and adult specimens at each temperature (Fig. 2B). The decrease of ETS activity in juveniles at the highest temperature $\left(32{ }^{\circ} \mathrm{C}\right)$ was likely related to reduced physiological fitness observed at the same condition, indicated by lower GLY content (furtherly discussed). Elevated temperatures may induce physiological stress due to increased metabolic activity and result in reduced fitness (Hering et al., 2010). It is likely that juvenile oysters maintained at $32{ }^{\circ} \mathrm{C}$ were shifting into a moderate stress status, with the associated expenditure of energetic reserves (GLY) and lower GSH/GSSG, indicating an oxidative status (Sokolova et al., 2012). Juvenile C. brasiliana may have induced a decrease of active ETS enzyme concentrations at this temperature as an energetic trade-off mechanism. Adult $C$. brasiliana did not present the same pattern than juveniles, presenting no change in metabolic potential (ETS) and energetic reserves (GLY) among temperatures. Adult bivalves may present lower metabolic activity (Sukhotin and Pörtner, 2001), and therefore energetic reserves could suffice to maintain ETS concentrations equal among temperatures. No change of metabolic potential within the thermal range in adults could result from the fact that respiratory enzymes tend to remain fully active within the organisms thermal tolerance range (Simčič et al., 2014; Yurista, 1999), in accordance with the fact that tested temperatures were similar to the natural temperature range described for the species geographical distribution $\left(20\right.$ to $32{ }^{\circ} \mathrm{C}$ ) (Menzel, 1991). No change of ETS potential between juvenile and adult $C$. brasiliana can be related to other factors rather than body size. Interspecific and intraspecific dependence of energy metabolism on body weight can be different among different taxonomic and zoogeographic types of bivalve species (Nguyen et al., 2011; Vladimirova et al., 2003). Fanslow et al. (2001) stated that bivalves can maintain metabolic enzymatic complexes (ETS) at high levels throughout the year as an advantage towards seasonal variations in food availability and quality. Indeed, primary production and thus food availability is highly variable in the mangrove system where oysters were collected (Schaeffer-Novelli et al., 1990), and could be a reason for juvenile and adult $C$. brasiliana to present high ETS. Mangrove systems are naturally characterized by low oxygen concentrations in water (Robertson and Phillips, 1995). It is possible that $C$. brasiliana might sustain high concentrations of ETS units in order to enhance aerobic performance under low oxygen concentrations. Simčič et al. (2005) demonstrated that amphipod species adapted to low oxygen concentrations exhibit higher metabolic potential (ratio between ETS and respiration) compared to closely related congeners habiting oxygen rich waters.

The ETS activity was consistently different between both species, in both juveniles and adults (Table I). The above mentioned hypothesis may explain why juvenile and adult $C$. brasiliana presented similar ETS activities, and may also justify significantly higher ETS observed in the native species than in C. gigas, that could be related to different habitat characteristics, and require further investigation.

\subsection{Energy reserves}

GLY is the most important carbohydrate stored in bivalve tissues (Beukema, 1997), and can be simultaneously used as an energy source as well as for gametogenesis (Deslous-Paoli and Héral, 1988). Several studies have used GLY content as a measure of bivalves physiological response to environmental stressors such as salinity shifts, pollutant contamination and high $p \mathrm{CO}_{2}$ (Carregosa et al., 2014; Freitas et al., 2016; Velez et al., 2016).

C. gigas juveniles presented a significant decrease in GLY content with the increase of temperature from 24 to $28^{\circ} \mathrm{C}$. Adults also presented a decreasing trend in GLY content in oysters maintained at 28 and $32{ }^{\circ} \mathrm{C}$ in comparison to the lowest temperature $\left(24^{\circ} \mathrm{C}\right)$, although no significant differences were observed. $C$. gigas juveniles presented significantly higher GLY content than adults at $24^{\circ} \mathrm{C}$ (Fig. 3A). Lower GLY content in juveniles at $28{ }^{\circ} \mathrm{C}$, revealed increased energetic burden with the increase of temperature. In light of the Energy-Limited Tolerance concept (Sokolova et al., 2012), these results suggest that the optimum temperature for juvenile $C$. gigas was between 24 and $28^{\circ} \mathrm{C}$, since energetic balance was negative between these temperature levels. The increase of energy demand to cope with high temperature and consequent GLY depletion, likely led to high mortality at $32{ }^{\circ} \mathrm{C}$ in $\mathrm{C}$. gigas juveniles. Similarly, Flores-Vergara et al. (2004) observed increased mortality in C. gigas spat reared up to 6 weeks at $32^{\circ} \mathrm{C}$, and also showed progressive energetic depletion measured as carbohydrate content with increasing 


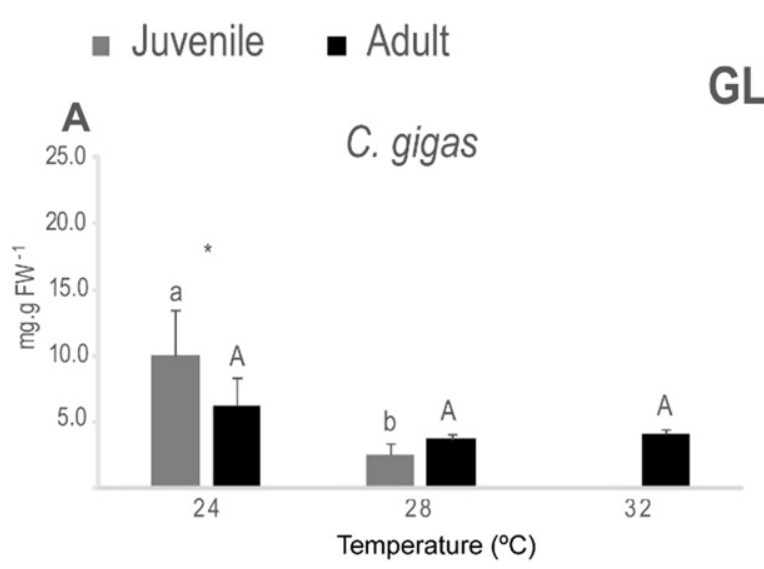

\section{GLY}

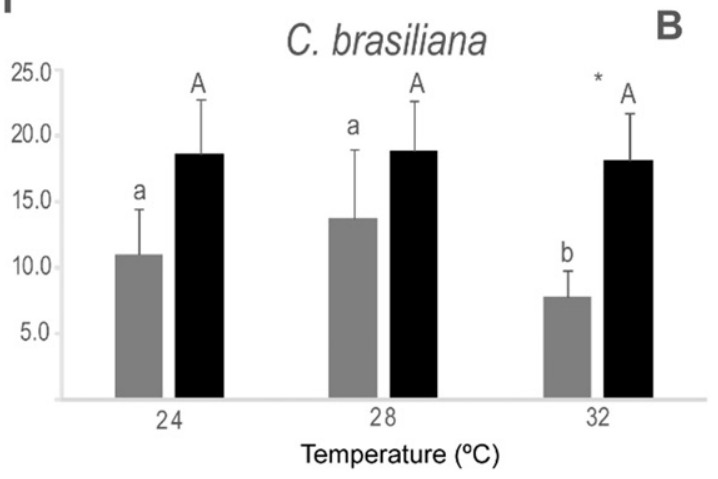

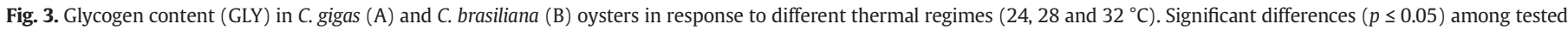

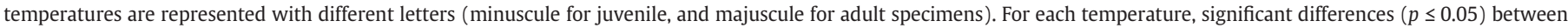
juvenile and adult oysters are represented with an asterisk (mean $\pm S D$; juveniles $n=8-12$; adults $n=6$ ).

temperatures $\left(23,26,29\right.$ and $\left.32{ }^{\circ} \mathrm{C}\right)$. No significant changes noted in GLY content in adults, could result from metabolic depression. A negative energetic balance could be expected in these oysters since results on the ETS suggest that the upper thermal limit was exceeded (Sokolova et al., 2012). However, molluscs are capable of decreasing the glycolytic flux and ATP consumption, as a means of GLY reserves maintenance to extend survival during periods of stress (Brooks and Storey, 1997; Storey, 1998), and could explain constant GLY levels observed.

C. brasiliana, juveniles presented significantly lower GLY content at $32^{\circ}$, compared to oysters maintained at 24 and $28^{\circ} \mathrm{C}$. Adult $\mathrm{C}$. brasiliana showed no significant changes in GLY content among different temperatures. Adults presented consistently higher GLY content than juveniles in all conditions, although only statistically significant at 24 and $32{ }^{\circ} \mathrm{C}$ (Fig. 3B). Lower GLY content in juvenile C. brasiliana at $32^{\circ} \mathrm{C}$, could result from a shift to a moderate stress status (Sokolova et al., 2012), and therefore may indicate an upper thermal tolerance limit close to the highest temperature. Adults did not present alterations in GLY content with increasing temperature, an indication that the thermal range did not induce higher energetic burden, or that glycolytic flux was down-regulated (Storey, 1998).

Overall, results show significantly higher GLY content observed in C. brasiliana than in C. gigas (Table 1 ), in both adult and juveniles at all temperature levels except for juveniles at $24^{\circ} \mathrm{C}$. These results could be attributed to variations in each species reproductive strategy. C. brasiliana from south Brazilian estuaries does not follow a fixed seasonal spawning pattern, oysters can be found at all development stages during the year (Castilho-Westphal et al., 2015; Galvão et al., 2013; Gomes et al., 2014), and may therefore hold higher GLY content year round.

\subsection{Antioxidant response}

Adaptation to thermal variations can cause shifts of the antioxidant defence status of marine bivalve species (Abele et al., 2002; Dimitriadis et al., 2012; Lockwood et al., 2010; Tomanek and Zuzow, 2010), and can be influenced by changes in metabolism and membrane phospholipid structure that may alter ROS production rates and sources (Pörtner, 2010; Sappal et al., 2015). SOD is one of the most important antioxidant enzyme that catalyses free radicals, and has been shown to reflect ambient temperature in bivalves such as Mytilus edulis (Lesser et al., 2010), Perna viridis (Verlecar et al., 2007), and Scapharca broughtonii (An and Choi, 2010).

Results obtained for SOD in juvenile $C$. gigas show a significant increase in activity with the increase of temperature from 24 to $28{ }^{\circ} \mathrm{C}$. Adult specimens presented similar activities among tested temperatures. Juvenile and adult $C$. gigas presented significant differences in SOD activity at $28^{\circ} \mathrm{C}$, with higher values observed in juveniles compared to adults (Fig. 4A). Higher SOD activity observed in juvenile C. gigas maintained at $28{ }^{\circ} \mathrm{C}$, could relate to species metabolic adjustment. Metabolic adaptation during transitions from metabolically active states to arrested metabolic states in response to stress, organisms may experience what can be defined as moderate stress (Sokolova et al., 2012). At this physiological status, organisms develop several mechanisms to mitigate the impacts of a given stressor. These are energetically costly, and can include increased metabolic rates and upregulation of cellular protection mechanisms, such as antioxidant enzyme SOD (Sokolova et al., 2012; Tomanek, 2014). As previously noted, significantly lower GLY in juvenile $\mathrm{C}$. gigas at $28{ }^{\circ} \mathrm{C}$, indicate a mismatch between energy supply and demand, a characteristic of a shift to a moderate stress status (Sokolova et al., 2012; Sokolova and Lannig, 2008) at $28{ }^{\circ} \mathrm{C}$. Additionally, increased SOD activity shows upregulation of antioxidant defences towards suboptimal temperature.

Regarding C. brasiliana, juveniles presented significantly different SOD activity values among all acclimation temperatures, with the highest activity values observed at the lowest temperature $\left(24^{\circ} \mathrm{C}\right)$ and the lowest SOD activities at $28{ }^{\circ} \mathrm{C}$. On the contrary, adult C. brasiliana presented similar SOD activity values among all tested temperatures. Significant differences between juvenile and adult specimens were only noticed at $28{ }^{\circ} \mathrm{C}$, with higher activity values observed in adults as opposed to juveniles (Fig. 4B). Higher SOD activity in juvenile C. brasiliana maintained at $24{ }^{\circ} \mathrm{C}$ could relate to higher proportions of polyunsaturated fatty acids (PUFA) in membranes, characteristic of homeoviscous adaptation to lower temperatures (Crockett, 2008). PUFA are highly susceptible to oxidation, and readily form lipid peroxyl radicals (Lira et al., 2013). We suggest that higher SOD activities at $24^{\circ} \mathrm{C}$ could be induced as a protective mechanism to prevent excessive PUFA oxidation in C. brasiliana. Adults presented similar SOD activity values than juveniles at $24{ }^{\circ} \mathrm{C}$, despite no change in SOD with the increase of temperature, where levels of active enzymes were kept constant. The differentiated results obtained regarding SOD activity between $C$. gigas and $C$. brasiliana juveniles, highlight different response patterns between both species to tested temperatures, with $C$. gigas presenting overall higher SOD activity at all tested temperatures, and significantly higher in juveniles at $28^{\circ} \mathrm{C}$ (Table I). Proteomic studies have shown differences in SOD expression profiles between other congeneric bivalve species, namely in mussels $M$. galloprovincialis and $M$. trossulus exposed to acute heat stress at 24,28 and $32{ }^{\circ} \mathrm{C}$, with increased SOD expression levels only observed in M. galloprovincialis at $28{ }^{\circ} \mathrm{C}$ (Tomanek and Zuzow, 2010). These results led authors to infer that these species present different cellular response mechanisms towards oxidative stress. 


\section{- Juvenile adult}
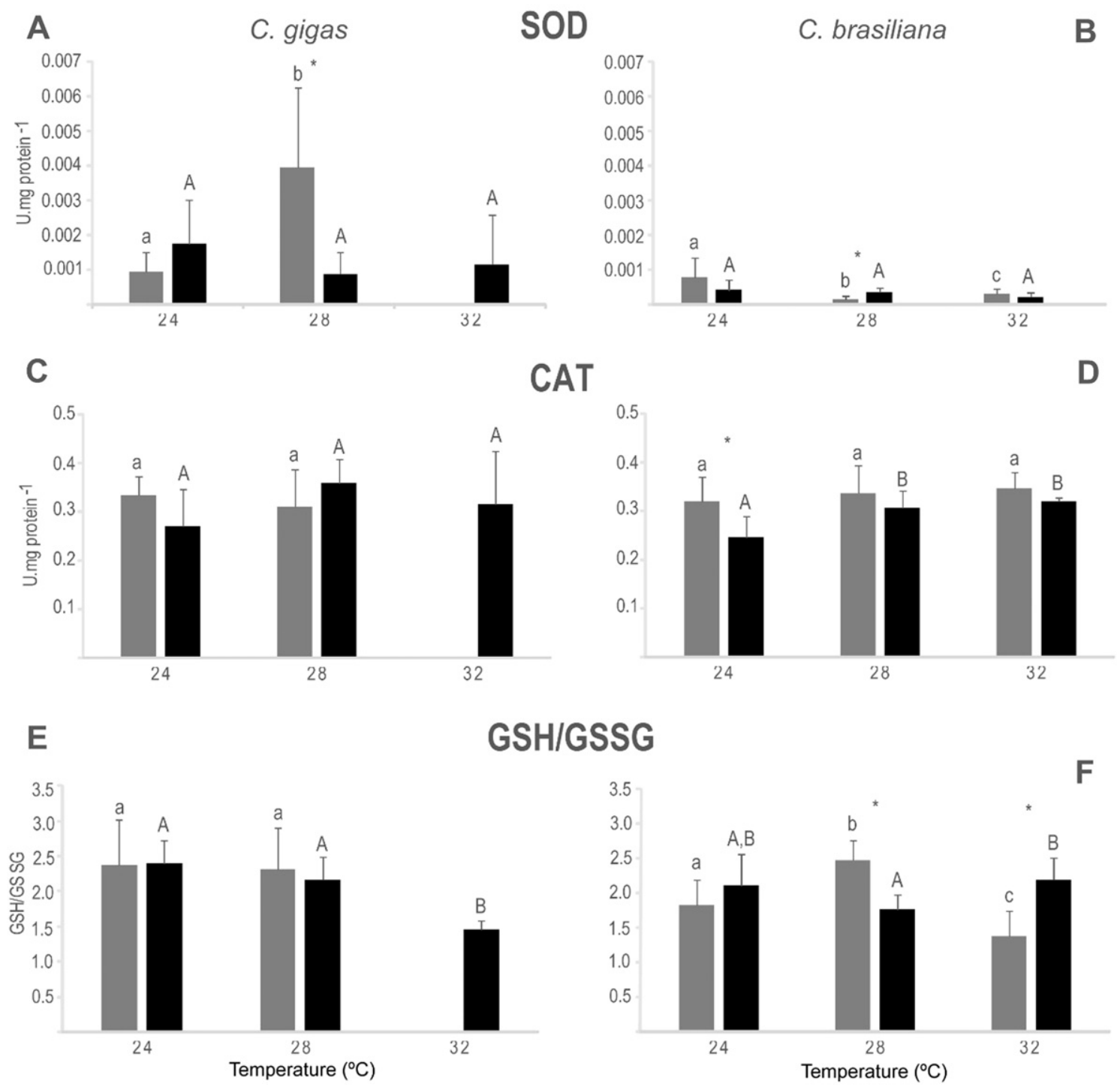

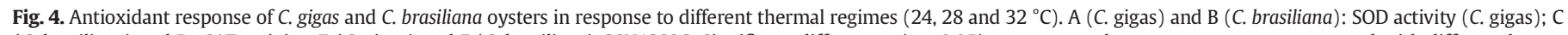

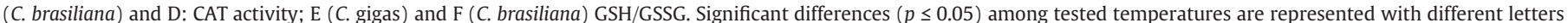

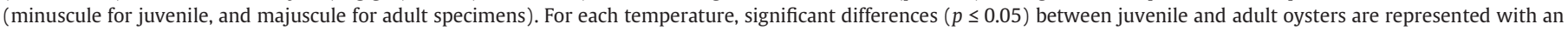
asterisk (mean $\pm S D$; juveniles $n=8-12$; adults $n=6$ ).

Similarly, our results also showed different SOD antioxidant capacities between species.

Results obtained for CAT activity in C. gigas, showed no significant differences among tested conditions, in either juveniles or adult specimens. Moreover, no significant differences were observed in CAT activity between juvenile and adults within each temperature level (Fig. 4C). An increase of CAT activity could be expected to occur in oysters that presented high SOD activity (juveniles at $28^{\circ} \mathrm{C}$ ) (Regoli and Giuliana, 2014). However, Béguel et al. (2013) suggested that $C$. gigas may preferentially use glutathione peroxidase (GPx), an alternative hydrogen peroxide $\left(\mathrm{H}_{2} \mathrm{O}_{2}\right)$ reducing enzyme (Halliwell and Gutteridge, 2015). Other studies have assessed CAT activity in bivalve species under different thermal regimes with contrasting results. For example, Matozzo et al. (2012) observed increased CAT in clams Chamelea gallina, and no alterations in mussels M. galloprovincialis maintained at 22 and $28^{\circ} \mathrm{C}$.

Regarding $C$. brasiliana, juveniles presented similar CAT activity values at different acclimation temperatures. Adults presented significantly higher CAT activity at higher temperatures (28 and $32{ }^{\circ} \mathrm{C}$ ) comparing to values observed at $24^{\circ} \mathrm{C}$. Differences in CAT activity between juvenile and adult oysters were only observed at $24{ }^{\circ} \mathrm{C}$, with juveniles presenting significantly higher activity values than adults (Fig. 4D). Increased CAT activity in C. brasiliana was only noted in adults at 28 and $32{ }^{\circ} \mathrm{C}$ relative to the lowest temperature, indicating that these oysters induced higher antioxidant capacity towards $\mathrm{H}_{2} \mathrm{O}_{2}$ at higher temperatures. Juveniles did not show the same pattern. Differences in antioxidant capacities between bivalve specimens of different ages can be expected to occur, although these do not always respond in the same pattern. For instance, CAT activity has shown to decrease with age in C. virginica (Ivanina et al., 2008) and M. edulis (Viarengo et al., 1991), or to remain constant as in M. edulis (Sukhotin et al., 2002), and L. elliptica (Philipp et al., 2005). These are in contrast to our findings for $C$. brasiliana, although they were obtained for wider ranges of ageing, different species and tissues than those from the present study. Mechanisms responsible for these patterns are still under debate (Ivanina et al., 2008). Our results further illustrate that different temperatures of exposure can yield different antioxidant response (CAT and SOD) 
among different life stages. Between species, no major differences were observed for CAT activity except at $28^{\circ} \mathrm{C}$, where CAT was higher in adult C. gigas (Table I).

Reduced glutathione (GSH) is the most important non-enzymatic cellular ROS scavenger, also serving as cofactor for several antioxidant enzymes (including GPx) and glutathione-S-transferases (GSTs). GSH is oxidized to GSSG during antioxidant processes (Regoli and Giuliani, 2014), and thus GSH/GSSG gives a measure of the antioxidant status of a given organism (Lesser, 2006).

Juvenile C. gigas presented no differences in GSH/GSSG between 24 and $28{ }^{\circ} \mathrm{C}$. Adult oysters presented significantly lower GSH/GSSG at $32{ }^{\circ} \mathrm{C}$, comparing to those acclimated to lower temperatures (24 and $28^{\circ} \mathrm{C}$ ). No significant differences were noted in GSH/GSSG between juvenile and adult $C$. gigas (Fig. 4E). Significantly lower GSH/GSSG in adults at $32{ }^{\circ} \mathrm{C}$ comparing to specimens at $28{ }^{\circ} \mathrm{C}$, indicate a prooxidant status at this temperature level. Lannig et al. (2006) also observed lower GSH/GSSG in C. virginica with increasing temperature, as well as a limited capacity of this species to synthesise GSH at high temperatures (up to $28^{\circ} \mathrm{C}$ ).

Concerning $C$. brasiliana, juveniles presented different GSH/GSSG at each temperature condition, with the highest value observed at $28{ }^{\circ} \mathrm{C}$, the lowest at $32{ }^{\circ} \mathrm{C}$, and an intermediate value at $24^{\circ} \mathrm{C}$. In C. brasiliana adults, significant differences were observed between oysters maintained at 32 and $28{ }^{\circ} \mathrm{C}$, with higher GSH/GSSG observed at the highest temperature $\left(32^{\circ} \mathrm{C}\right)$. Regarding differences between life stages, juveniles presented a significantly higher GSH/GSSG at $28{ }^{\circ} \mathrm{C}$, and lower ratio at $32{ }^{\circ} \mathrm{C}$ comparing to adults (Fig. $4 \mathrm{~F}$ ). The highest GSH/GSSG observed in juveniles at $28{ }^{\circ} \mathrm{C}$ resulted from high GSH concentrations observed (data not shown), resulting from increased GSH synthesis in response to increasing temperature (increased total glutathione levels). At $32{ }^{\circ} \mathrm{C}, \mathrm{GSH} / \mathrm{GSSG}$ in juvenile oysters was the lowest, as a result of higher proportions of oxidized GSSG, evidencing that oysters were in a prooxidant status (supported by results for GLY e ETS). In adult C. brasiliana, GSH/GSSG was higher at $32{ }^{\circ} \mathrm{C}$ comparing to $28^{\circ} \mathrm{C}$. However, the ratio was markedly influenced by a significant increase of GSH (data not shown), indicating that oysters were actively synthesising $\mathrm{GSH}$ at $32{ }^{\circ} \mathrm{C}$ in response to thermal stress.

Overall, our results suggest that $C$. brasiliana presented higher capacity to utilize GSH as an antioxidant than C. gigas that likely influenced response to thermal stress (higher total glutathione pool, data not shown). The use of GSH as an antioxidant can be energetically less costly than to induce antioxidant enzymes (Pannunzio and Storey, 1998), and could therefore present advantages for energetic fitness. The preferential use of GSH observed in C. brasiliana juveniles may be related to the use of metabolic pathways towards lower ROS production
(NADPH oriented and higher quenching GSH capacity, previously described for Mytillid species (Tomanek, 2014)).

\subsection{Lipid peroxidation}

Juvenile $C$. gigas presented a significant decrease of LPO with the increase of temperature from 24 to $28^{\circ} \mathrm{C}$. Adult oysters showed similar LPO levels between 24 and $28^{\circ} \mathrm{C}$, while at $32^{\circ} \mathrm{C}$ oysters presented significantly lower LPO levels compared to oysters at 24 and $28^{\circ} \mathrm{C}$. Significantly higher LPO levels were observed in juveniles in comparison to adults at $24^{\circ}$ (Fig. 5A).

Higher LPO levels observed in juvenile $C$. gigas at the lowest temperature $\left(24^{\circ} \mathrm{C}\right)$, as well in adults at temperatures 24 and $28^{\circ} \mathrm{C}$, can be explained by a number of mechanisms and their interactions, such as membrane structure, metabolic adjustment and antioxidant capacity. Temperature variations induce membrane restructuring in biological systems, a common response mechanism known to ectotherms (Crockett, 2008). The most important of these mechanisms involve changes of phospholipids unsaturation levels, with organisms commonly presenting higher membrane proportions of polyunsaturated fatty acids (PUFA), when either acclimated or acclimatized to lower temperatures (Hazel and Williams, 1990). The saturation state of biological membranes is likely to influence organisms susceptibility to LPO (Halliwell and Gutteridge, 2015; Crockett, 2008), since higher proportions of PUFA increase the propensity of membranes to peroxidation reactions (de Zwart et al., 1999). Higher LPO levels in juvenile C. gigas at $24^{\circ} \mathrm{C}$, could therefore be a result of higher PUFA proportions in membranes. Studies on C. gigas from the environment have correlated higher PUFA levels with lower temperatures in adults (Dagorn et al., 2016; Pazos et al., 1996), as well as in laboratory exposed spat $\left(23-32{ }^{\circ} \mathrm{C}\right)$ (Flores-Vergara et al., 2004). Increased LPO in juveniles at the lowest temperature could therefore be partially explained by this fatty acid composition, and has also been hypothesised for oysters collected in the environment (Zanette et al., 2006). However, LPO levels in adult $C$. gigas did not show the same response pattern, and suggest an age dependent function of LPO formation. Accordingly, Ivanina et al. (2008) observed higher rates of fluorescent ageing pigments (the end product of LPO) formation in younger individuals of $C$. virginica. These differences could be related to differentiated metabolic rates between age groups (Ivanina et al., 2008; Sukhotin and Pörtner, 2001). Higher metabolic activity in juveniles could render higher ROS as a function of size, or because older organisms can present depressed metabolic rates (Sukhotin and Pörtner, 2001). The decrease of LPO at $32{ }^{\circ} \mathrm{C}$ in adult oysters could be explained by the onset of anaerobiosis at the pessimum range of thermal tolerance (see Sokolova et al., 2012). Successful

\section{- Juvenile - Adult}

A C. gigas

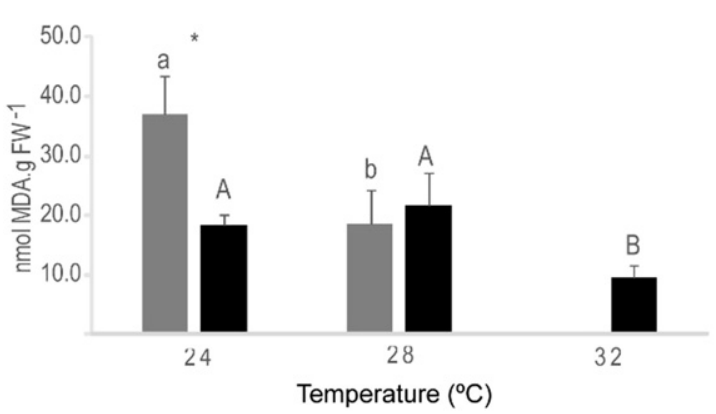

C. brasiliana

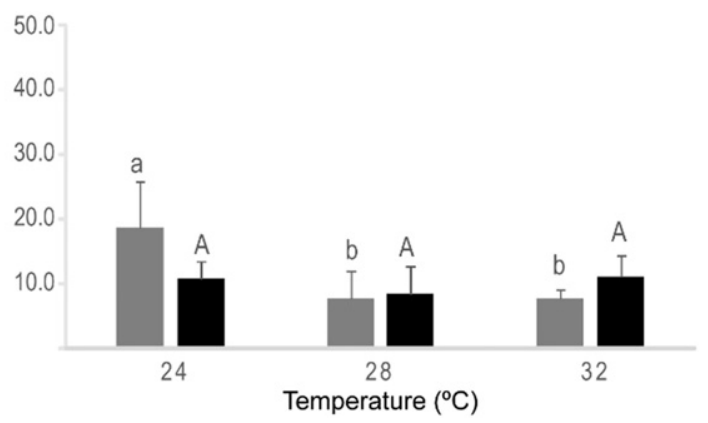

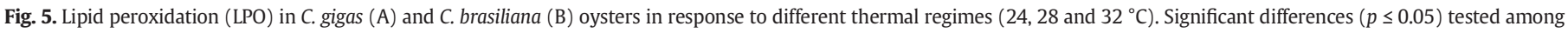

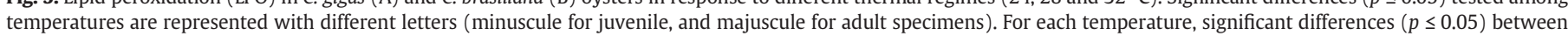
juvenile and adult oysters are represented with an asterisk (mean $\pm S D$; juveniles $n=8-12$; adults $n=6$ ). 
facultative anaerobes such as oysters can alternate between aerobic and anaerobic metabolism in response to conditions of extreme stress to minimize ROS production (Anestis et al., 2007; Pörtner, 2010; Tomanek, 2014). Rivera-Ingraham et al. (2013), showed lower ROS production in $M$. edulis under hypoxic conditions, that intertidal molluscs possess mechanisms that allow for anaerobic respiration with low deleterious free radical production. Several adaptive mechanisms are known to mitigate ROS formation in marine facultative anaerobes (see Abele et al., 2007). During anaerobic respiration such mechanisms are likely to become active and could explain lower LPO levels in adults comparing to lower temperatures where aerobic metabolism is probably more prevalent. Further investigation on aerobic and anaerobic respiration is required to understand these mechanisms.

Regarding $C$. brasiliana, juveniles presented significantly higher LPO levels at $24^{\circ} \mathrm{C}$, comparing to oysters at 28 and $32{ }^{\circ} \mathrm{C}$. Adults presented no significant differences on LPO levels among all acclimation temperatures. Comparing juvenile and adult oysters within the same temperature, no significant differences were observed at each temperature level (Fig. 5B). The highest LPO levels in C. brasiliana oysters were observed in juvenile at the lowest temperature $\left(24^{\circ} \mathrm{C}\right)$, which may result from higher PUFA proportions at lower temperatures and thus higher susceptibility to ROS. As for C. gigas, significantly higher levels of PUFA have been observed in C. rizhophorae (here identified as $C$. brasiliana) during winter $\left(24^{\circ} \mathrm{C}\right)$ (Lira et al., 2013; Martino and Cruz, 2004). PUFA are highly susceptible to oxidation, and readily form lipid peroxyl radicals (Lira et al., 2013). In adult oysters LPO was unchanged regardless of temperature level, and no differences were observed towards juveniles at the lowest temperature.

Results obtained showing significantly higher LPO levels in C. gigas than in C. brasiliana (Tabe I) for the majority of conditions tested (except for adult oysters at $32{ }^{\circ} \mathrm{C}$ ), likely resulted from the above mentioned differentiated response by the native and the introduced species (GSH or SOD oriented respectively), energy related metabolism among conditions (ETS and GLY) and species natural thermal range.

\section{Concluding remarks}

The present study illustrates the complexity of the biochemical response of two oyster species to different temperature levels, and reflects different species strategies to endure the tested thermal window. Overall, juveniles from both species showed to be more responsive to thermal regime than adults, presenting higher mortality, higher susceptibility to cellular damage, stimulated antioxidant response and energetic depletion, with results suggesting higher upper thermal tolerance in the native species. On the contrary, adult oysters showed to be less responsive to thermal stress. Comparison between species revealed that thermal stress induced greater alterations in C. gigas, with overall higher SOD activity comparing to $C$. brasiliana, also indicating greater energetic costs in response to increasing temperatures in $C$. gigas comparing to $C$. brasiliana. These results suggest that energetic metabolism of $C$. brasiliana was more efficient than that of $C$. gigas under the tested thermal window, and may be related to higher hypoxia tolerance in the native species which should be further investigated. Despite high mortality of juveniles, the introduced species presented mechanisms that allowed adults to be resilient to thermal stress, at temperatures higher than those predicted for C. gigas in South America (Carrasco and Barón, 2009). This study brings new insights on the biochemical mechanisms involved in the response of two important oyster species to different thermal regimes, and highlights the importance of studying different life stages in order to better understand the ecological impacts of environmental stressors. Results obtained indicate that $C$. gigas holds mechanisms that may enable it to survive at higher temperatures. The question remains if these mechanisms would be sufficient on the long term for the introduced species to survive such thermal regime. If adult are able to survive and spawn, increased resistance of offspring
(Parker et al., 2012) could enable for competition in a changing environment.

\section{References}

Abele, D., Heise, K., Pörtner, H.O., Puntarulo, S., 2002. Temperature-dependence of mitochondrial function and production of reactive oxygen species in the intertidal mud clam Mya arenaria. J. Exp. Biol. 205, 1831-1841.

Abele, D., Philipp, E., Gonzalez, P., Puntarulo, S., 2007. Marine invertebrate mitochondria and oxidative stress. Front. Biosci. 12, 933-946.

Almeida, Â. Calisto, V., Esteves, VI., Schneider, RJ Soares, A.M.V.M., Figueira, E. Freitas, R., 2014. Presence of the pharmaceutical drug carbamazepine in coastal systems: effects on bivalves. Aquat. Toxicol. 156:74-87. http://dx.doi.org/10.1016/j.aquatox. 2014.08.002.

An, M.I., Choi, C.Y., 2010. Activity of antioxidant enzymes and physiological responses in ark shell, Scapharca broughtonii, exposed to thermal and osmotic stress: effects on hemolymph and biochemical parameters. Comp. Biochem. Physiol. B Biochem. Mol. Biol. 155, 34-42.

Anderson, M., Gorley, R.N., Clarke, R.K., 2008. Permanova + for Primer: Guide to Software and Statisticl Methods.

Anestis, A., Lazou, A., Pörtner, H.O., Michaelidis, B., 2007. Behavioral, metabolic, and molecular stress responses of marine bivalve Mytilus galloprovincialis during long-term acclimation at increasing ambient temperature. Am. J. Physiol. Regul. Integr. Comp. Physiol. 293, R911-R921.

Angilletta, M.J., 2009. Thermal Adaptation: A Theoretical and Empirical Synthesis. OUP, Oxford.

Båmstedt, U., 1980. ETS activity as an estimator of respiratory rate of zooplankton populations. The significance of variations in environmental factors. J. Exp. Mar. Biol. Ecol. 42:267-283. http://dx.doi.org/10.1016/0022-0981(80)90181-1.

Beauchamp, C., Fridovich, I., 1971. Superoxide dismutase: improved assays and an assay applicable to acrylamide gels. Anal. Biochem. 44, 276-287.

Béguel, J.-P., Huvet, A., Quillien, V., Lambert, C., Fabioux, C., 2013. Study of the antioxidant capacity in gills of the Pacific oyster Crassostrea gigas in link with its reproductive investment. Comp. Biochem. Physiol. C Toxicol. Pharmacol. 157:63-71. http://dx.doi. org/10.1016/j.cbpc.2012.10.004.

Berridge, M.V., Herst, P.M., Tan, A.S., 2005. Tetrazolium dyes as tools in cell biology: new insights into their cellular reduction. Biotechnol. Annu. Rev. 11, 127-152.

Beukema, J.J., 1997. Caloric values of marine invertebrates with an emphasis on the soft parts of marine bivalves. Oceanogr. Mar. Biol. Annu. Rev.

Brierley, A.S., Kingsford, M.J., 2009. Impacts of climate change on marine organisms and ecosystems. Curr. Biol. 19:R602-R614. http://dx.doi.org/10.1016/j.cub.2009.05.046.

Brooks, S.P.J., Storey, K.B., 1997. Glycolytic controls in estivation and anoxia: a comparison of metabolic arrest in land and marine molluscs. Comp. Biochem. Physiol. A Physiol. 118:1103-1114. http://dx.doi.org/10.1016/S0300-9629(97)00237-5.

Carranza, A., Defeo, O., Beck, M., 2009. Diversity, conservation status and threats to native oysters (Ostreidae) around the Atlantic and Caribbean coasts of South America. Aquat. Conserv. Mar. Freshwat. Ecosyst. 19:344-353. http://dx.doi. org/10.1002/aqc.993.

Carrasco, M.F., Barón, P.J., 2009. Analysis of the potential geographic range of the Pacific oyster Crassostrea gigas (Thunberg, 1793) based on surface seawater temperature satellite data and climate charts: the coast of South America as a study case. Biol. Invasions 12:2597-2607. http://dx.doi.org/10.1007/s10530-009-9668-0.

Carregosa, V., Velez, C., Soares, A.M.V.M., Figueira, E., Freitas, R., 2014. Physiological and biochemical responses of three Veneridae clams exposed to salinity changes. Comp. Biochem. Physiol. B Biochem. Mol. Biol. 177-178:1-9. http://dx.doi.org/10.1016/j. cbpb.2014.08.001.

Castilho-Westphal, G.G., Magnani, F.P., Ostrensky, A., 2015. Gonad morphology and reproductive cycle of the mangrove oyster Crassostrea brasiliana (Lamarck, 1819) in the baía de Guaratuba, Paraná, Brazil. Acta Zool. 96:99-107. http://dx.doi.org/10.1111/ azo.12055.

Cheung, W.W.L., Lam, V.W.Y., Sarmiento, J.L., Kearney, K., Watson, R., Pauly, D., 2009. Projecting global marine biodiversity impacts under climate change scenarios. Fish Fish. 10:235-251. http://dx.doi.org/10.1111/j.1467-2979.2008.00315.x.

Coen, L.D., Brumbaugh, R.D., Bushek, D., Grizzle, R., Luckenbach, M.W., Posey, M.H., Powers, S.P., Tolley, S.G., 2007. Ecosystem services related to oyster restoration. Mar. Ecol. Prog. Ser. 341:303-307. http://dx.doi.org/10.3354/meps341303.

Crockett, E.L., 2008. The cold but not hard fats in ectotherms: consequences of lipid restructuring on susceptibility of biological membranes to peroxidation, a review. J. Comp. Physiol. B. 178:795-809. http://dx.doi.org/10.1007/s00360-008-0275-7.

Dagorn, F., Couzinet-Mossion, A., Kendel, M., Beninger, P.G., Rabesaotra, V., Barnathan, G., Wielgosz-Collin, G., 2016. Exploitable lipids and fatty acids in the invasive oyster Crassostrea gigas on the French Atlantic Coast. Mar. Drugs 14. http://dx.doi.org/10. 3390/md14060104.

De Coen, W.M., Janssen, C.R., 1997. The use of biomarkers in Daphnia magna toxicity testing. IV. Cellular energy allocation: a new methodology to assess the energy budget of toxicant-stressed Daphnia populations. J. Aquat. Ecosyst. Stress. Recover. 6, 43-55.

de Zwart, L.L., Meerman, J.H., Commandeur, J.N., Vermeulen, N.P., 1999. Biomarkers of free radical damage applications in experimental animals and in humans. Free Radic. Biol. Med. 26, 202-226.

Deslous-Paoli, J.-M., Héral, M., 1988. Biochemical composition and energy value of Crassostrea gigas (Thunberg) cultured in the bay of Marennes-Oléron. Aquat. Living Resour. 1, 239-249.

Devol, A.H., Packard, T.T., 1978. Seasonal changes in respiratory enzyme activity productivity in Lake Washington microplankton. Limnol. Oceanogr. 23:104-111. http://dx. doi.org/10.4319/lo.1978.23.1.0104. 
Diederich, S., Nehls, G., van Beusekom, J.E.E., Reise, K., 2005. Introduced Pacific oysters (Crassostrea gigas) in the northern Wadden Sea: invasion accelerated by warm summers? Helgol. Mar. Res. 59:97-106. http://dx.doi.org/10.1007/s10152-004-0195-1.

Dimitriadis, V.K., Gougoula, C., Anestis, A., Pörtner, H.O., Michaelidis, B., 2012. Monitoring the biochemical and cellular responses of marine bivalves during thermal stress by using biomarkers. Mar. Environ. Res. 73:70-77. http://dx.doi.org/10.1016/j.marenvres.2011. 11.004.

Doney, S.C., Ruckelshaus, M., Emmett Duffy, J., Barry, J.P., Chan, F., English, C.A., Galindo, H.M., Grebmeier, J.M., Hollowed, A.B., Knowlton, N., Polovina, J., Rabalais, N.N., Sydeman, W.J., Talley, L.D., 2012. Climate change impacts on marine ecosystems. Annu. Rev. Mar. Sci. 4:11-37. http://dx.doi.org/10.1146/ annurev-marine-041911-111611.

Fanslow, D.L., Nalepa, T.F., Johengen, T.H., 2001. Seasonal changes in the respiratory electron transport system (ETS) and respiration of the zebra mussel, Dreissena polymorpha in Saginaw Bay, Lake Huron. Hydrobiologia 448:61-70. http://dx.doi. org/10.1023/A:1017582119098.

FAO, 2012. The State of World Fisheries and Aquaculture - 2012. Food and Agriculture Organization of the United Nations, Rome, Italy, p. 209.

Flores-Vergara, C., Cordero-Esquivel, B., Cerón-Ortiz, A.N., Arredondo-Vega, B.O., 2004. Combined effects of temperature and diet on growth and biochemical composition of the Pacific oyster Crassostrea gigas (Thunberg) spat. Aquac. Res. 35:1131-1140. http://dx.doi.org/10.1111/j.1365-2109.2004.01136.x.

Folmer, R., Black, M., Hoeh, W., Lutz, R., Vrijenhoek, R., 1994. DNA primers for amplification of mitochondrial cytochrome $c$ oxidase subunit I from diverse metazoan invertebrates. Mol. Mar. Biol. Biotechnol. 3, 294-299.

Freitas, R., Pires, A., Moreira, A., Wrona, F.J., Figueira, E., Soares, A.M.V.M., 2016. Biochemical alterations induced in Hediste diversicolor under seawater acidification conditions. Mar. Environ. Res. 117:75-84. http://dx.doi.org/10.1016/j.marenvres.2016.04.003.

Francis, R.A., 2012. A Handbook of Global Freshwater Invasive Species. Earthscan, Oxon and New-York, p. 456.

Galvão, M.S.N., Pereira, O.M., Hilsdorf, A.W.S., 2013. Molecular identification and distribution of mangrove oysters (Crassostrea) in an estuarine ecosystem in Southeast Brazil: implications for aquaculture and fisheries management. Aquac. Res. 44:1589-1601. http://dx.doi.org/10.1111/j.1365-2109.2012.03166.x.

Gomes, C., Silva, F.C., Lopes, G.R., Melo, C.M.R., 2014. The reproductive cycle of the oyster Crassostrea gasar. Braz. J. Biol. 74, 967-976.

Grabowski, J.H., Brumbaugh, R.D., Conrad, R.F., Keeler, A.G., Opaluch, J.J., Peterson, C.H., Piehler, M.F., Powers, S.P., Smyth, A.R., 2012. Economic valuation of ecosystem services provided by oyster reefs. Bioscience 62:900-909. http://dx.doi.org/10.1525/ bio.2012.62.10.10.

Greco, L., Pellerin, J., Capri, E., Garnerot, F., Louis, S., Fournier, M., Sacchi, A., Fusi, M., Lapointe, D., Couture, P., 2011. Physiological effects of temperature and a herbicide mixture on the soft-shell clam Mya arenaria (Mollusca, Bivalvia). Environ. Toxicol. Chem. SETAC 30:132-141. http://dx.doi.org/10.1002/etc.359.

Grizel, H., Héral, M., 1991. Introduction into France of the Japanese oyster (Crassostrea gigas). J. Cons. ICES J. Mar. Sci. 47:399-403. http://dx.doi.org/10.1093/icesjms/47.3. 399.

Halliwell, B., Gutteridge, J.M.C., 2015. Free Radicals in Biology and Medicine. Oxford University Press.

Hansen, J., Kharecha, P., Sato, M., Masson-Delmotte, V., Ackerman, F., Beerling, D.J., Hearty, P.J., Hoegh-Guldberg, O., Hsu, S.-L., Parmesan, C., Rockstrom, J., Rohling, E.J., Sachs, J., Smith, P., Steffen, K., Susteren, L.V., von Schuckmann, K., Zachos, J.C., 2013. Assessing "dangerous climate change": required reduction of carbon emissions to protect young people, future generations and nature. PLoS One 8, e81648. http://dx.doi.org/ 10.1371/journal.pone.0081648.

Harley, C.D.G., Randall Hughes, A., Hultgren, K.M., Miner, B.G., Sorte, C.J.B., Thornber, C.S. Rodriguez, L.F., Tomanek, L., Williams, S.L., 2006. The impacts of climate change in coastal marine systems. Ecol. Lett. 9:228-241. http://dx.doi.org/10.1111/j.14610248.2005.00871.X.

Hawkins, A.J.S., 1995. Temperature-dependence of mitochondrial function and production of reactive oxygen species in the intertidal mud clam Mya arenaria. J. Therm. Biol. 20:23-33. http://dx.doi.org/10.1016/0306-4565(94)00023-C (Effects of Rising Temperature on the Ecology and Physiology of Aquatic Organisms).

Hazel, J.R., Williams, E.E., 1990. The role of alterations in membrane lipid composition in enabling physiological adaptation of organisms to their physical environment. Prog. Lipid Res. 29, 167-227.

Hering, D., Haidekker, A., Schmidt-Kloiber, A., Barker, T., Buisson, L., Graf, W., Grenouillet, G., Lorenz, A., Sandin, L., Stendera, S., 2010. Monitoring the responses of freshwater ecosystems to climate change. In: Kernan, M., Battarbee, R.W., Moss, B. (Eds.), Climate Change Impacts on Freshwater Ecosystems. Wiley-Blackwell, pp. 84-118.

IPCC, 2013. Climate change 2013: the physical science basis. In: Stocker, T.F., Qin, D., Plattner, G.-K., Tignor, M., Allen, S.K., Boschung, J., Nauels, A., Xia, Y., Bex, V., Midgley, P.M. (Eds.), Contribution of Working Group I to the Fifth Assessment Report of the Intergovernmental Panel on Climate Change. Cambridge University Press, Cambridge, United Kingdom and New York, NY, USA http://dx.doi.org/10.1017/ CBO9781107415324 (1535 pp.).

Ivanina, A.V., Sokolova, I.M., Sukhotin, A.A., 2008. Oxidative stress and expression of chaperones in aging mollusks. Comp. Biochem. Physiol. B Biochem. Mol. Biol. 150:53-61. http://dx.doi.org/10.1016/j.cbpb.2008.01.005.

Johansson, L.H., Borg, L.A.H., 1988. A spectrophotometric method for determination of catalase activity in small tissue samples. Anal. Biochem. 174, 331-336.

Kerckhof, F., Haelters, J., Gollasch, S., et al., 2007. Alien species in the marine and brackish ecosystem: the situation in Belgian waters. Aquat. Invasions 2, 243-257.

King, F.D., Packard, T.T., 1975. Respiration and the activity of the respiratory electron transport system in marine zooplankton1. Limnol. Oceanogr. 20:849-854. http://dx. doi.org/10.4319/lo.1975.20.5.0849.
Krassoi, F.R., Brown, K.R., Bishop, M.J., Kelaher, B.P., Summerhayes, S., 2008. Conditionspecific competition allows coexistence of competitively superior exotic oysters with native oysters. J. Anim. Ecol. 77:5-15. http://dx.doi.org/10.1111/j.1365-2656. 2007.01316.x

Lannig, G., Flores, J.F., Sokolova, I.M., 2006. Temperature-dependent stress response in oysters, Crassostrea virginica: pollution reduces temperature tolerance in oysters. Aquat. Toxicol. Amst. Neth. 79:278-287. http://dx.doi.org/10.1016/j.aquatox.2006 06.017.

Le Moullac, G., Quéau, I., Le Souchu, P., Pouvreau, S., Moal, J., René Le Coz, J., François Samain, J., 2007. Metabolic adjustments in the oyster Crassostrea gigas according to oxygen level and temperature. Mar. Biol. Res. 3, 357-366.

Lejart, M., Clavier, J., Chauvaud, L., Hily, C., 2011. Respiration and calcification of Crassostred gigas: contribution of an intertidal invasive species to coastal ecosystem $\mathrm{CO}_{2}$ fluxes. Estuar. Coasts 35:622-632. http://dx.doi.org/10.1007/s12237-011-9462-y.

Lesser, M.P., 2006. Oxidative stress in marine environments: biochemistry and physiological ecology. Annu. Rev. Physiol. 68:253-278. http://dx.doi.org/10.1146/annurev. physiol.68.040104.110001.

Lesser, M.P., Kruse, V.A., 2004. Seasonal temperature compensation in the horse mussel, Modiolus modiolus: metabolic enzymes, oxidative stress and heat shock proteins. Comp. Biochem. Physiol. A Mol. Integr. Physiol. 137:495-504. http://dx.doi.org/10. 1016/j.cbpb.2003.10.022.

Lesser, M.P., Bailey, M.A., Merselis, D.G., Morrison, J.R., 2010. Physiological response of the blue mussel Mytilus edulis to differences in food and temperature in the Gulf of Maine. Comp. Biochem. Physiol. A Mol. Integr. Physiol. 156:541-551. http://dx.doi. org/10.1016/j.cbpa.2010.04.012.

Lira, G.M., Pascoal, J.C.M., Torres, E.A.F.S., Soares, R.A.M., Mendonça, S., Sampaio, G.R Correia, M.S., Cabral, C.C.V.Q., Cabral Júnior, C.R., López, A.M.Q., 2013. Influence of seasonality on the chemical composition of oysters (Crassostrea rhizophorae). Food Chem. 138:786-790. http://dx.doi.org/10.1016/j.foodchem.2012.11.088.

Lockwood, B.L., Sanders, J.G., Somero, G.N., 2010. Transcriptomic responses to heat stress in invasive and native blue mussels (genus Mytilus): molecular correlates of invasive success. J. Exp. Biol. 213:3548-3558. http://dx.doi.org/10.1242/jeb.046094.

Martino, R.C., Cruz, G.M., 2004. Proximate composition and fatty acid content of the mangrove oyster Crassostrea rhizophorae along the year seasons. Braz. Arch. Biol. Technol. 47:955-960. http://dx.doi.org/10.1590/S1516-89132004000600015.

Matozzo, V., Chinellato, A., Munari, M., Finos, L., Bressan, M., Marin, M.G., 2012. First evidence of immunomodulation in bivalves under seawater acidification and increased temperature. PLoS One 7, e33820. http://dx.doi.org/10.1371/journal.pone.0033820.

Mckindsey, C.W., Landry, T., O'beirn, F.X., Davies, I.M., 2007. Bivalve aquaculture and exotic species: a review of ecological considerations and management issues. J. Shellfish Res. 26:281-294. http://dx.doi.org/10.2983/0730-8000.

Melo, A.G.C., Varela, E.S., Beasley, C.R., Schneider, H., Sampaio, I., Gaffney, P.M., Reece, K.S. Tagliaro, C.H., 2010. Molecular identification, phylogeny and geographic distribution of Brazilian mangrove oysters (Crassostrea). Genet. Mol. Biol. 33:564-572. http://dx doi.org/10.1590/S1415-47572010000300030.

Mendonça, J.T., Machado, I.C., 2010. Mangrove oyster (Crassostrea spp.) (Sacco, 1897) extractivism in Cananéia estuary (São Paulo, Brazil) from 1999 to 2006: capture and management evaluation. Braz. J. Biol. 70:65-73. http://dx.doi.org/10.1590/ S1519-69842010000100010.

Menzel, W., 1991. Estuarine and Marine Bivalve Mollusk Culture. CRC Press.

Miossec, L., Le Deuff, R.-M., Goulletquer, P., 2009. Alien species alert: Crassostrea gigas (Pacific oyster). ICES Coop. Res. Rep. 299.

Moreira, A., Figueira, E., Soares, A.M.V.M., Freitas, R., 2016. The effects of arsenic and seawater acidification on antioxidant and biomineralization responses in two closely related Crassostrea species. Sci. Total Environ. 545-546:569-581. http://dx.doi.org/10. 1016/j.scitotenv.2015.12.029.

Nalepa, T.F., Fanslow, D.L., Pothoven, S.A., 2010. Recent changes in density, biomass, recruitment, size structure, and nutritional state of Dreissena populations in southern Lake Michigan. J. Gt. Lakes Res. 36 (Supplement 3):5-19. http://dx.doi.org/10.1016/ j.jglr.2010.03.013 (The Lower Food Web of Lake Michigan: Long-term Trends and the Dreissenid Impact).

Neto, R.M., Zeni, T.O., Ludwig, S., Horodesky, A., Girotto, M.V.F., Castilho-Westphal, G.G. Ostrensky, A., 2013. Influence of environmental variables on the growth and reproductive cycle of Crassostrea (Mollusca, Bivalvia) in Guaratuba Bay, Brazil. Invertebr. Reprod. Dev. 57:208-218. http://dx.doi.org/10.1080/07924259.2012.747449.

Nguyen, K.D.T., Morley, S.A., Lai, C.-H., Clark, M.S., Tan, K.S., Bates, A.E., Peck, L.S., 2011. Upper temperature limits of tropical marine ectotherms: global warming implications. PLoS One 6, e29340. http://dx.doi.org/10.1371/journal.pone. 0029340.

Occhipinti-Ambrogi, A., 2007. Global change and marine communities: alien species and climate change. Mar. Pollut. Bull. 55:342-352. http://dx.doi.org/10.1016/j.marpolbul. 2006.11.014 (Marine Bioinvasions: A collection of reviews).

Ohkawa, H., Ohishi, N., Yagi, K., 1979. Assay for lipid peroxides in animal tissues by thiobarbituric acid reaction. Anal. Biochem. 95, 351-358.

Packard, T.T., Devol, A.H., King, F.D., 1975. The effect of temperature on the respiratory electron transport system in marine plankton. Deep Sea Res. Oceanogr. Abstr. 22: 237-249. http://dx.doi.org/10.1016/0011-7471(75)90029-7.

Pannunzio, T.M., Storey, K.B., 1998. Antioxidant defenses and lipid peroxidation during anoxia stress and aerobic recovery in the marine gastropod Littorina littorea. J. Exp. Mar. Biol. Ecol. 221, 277-292.

Parker, L.M., Ross, P.M., O'Connor, W.A., Borysko, L., Raftos, D.A., Pörtner, H.-O., 2012. Adult exposure influences offspring response to ocean acidification in oysters. Glob. Chang. Biol. 18:82-92. http://dx.doi.org/10.1111/j.1365-2486.2011.02520.x.

Parker, L.M., Ross, P.M., O'Connor, W.A., Pörtner, H.O., Scanes, E., Wright, J.M., 2013. Predicting the response of molluscs to the impact of ocean acidification. Biology 2: 651-692. http://dx.doi.org/10.3390/biology2020651. 
Pazos, A.J., Ruíz, C., García-Martin, O., Abad, M., Sánchez, J., 1996. Seasonal variations of the lipid content and fatty acid composition of Crassostrea gigas cultured in E1 Grove, Galicia, N.W. Spain. Comp. Biochem. Physiol. B Biochem. Mol. Biol. 114:171-179. http:// dx.doi.org/10.1016/0305-0491(96)00017-X.

Philipp, E., Brey, T., Pörtner, H.-O., Abele, D., 2005. Chronological and physiological ageing in a polar and a temperate mud clam. Mech. Ageing Dev. 126:598-609. http://dx.doi. org/10.1016/j.mad.2004.12.003.

Pie, M.R., Ribeiro, R.O., Boeger, W.A., Ostrensky, A., Falleiros, R.M., Angelo, L., 2006. A simple PCR-RFLP method for the discrimination of native and introduced oyster species (Crassostrea brasiliana, C. rhizophorae and C. gigas; Bivalvia: Ostreidae) cultured in Southern Brazil. Aquac. Res. 37, 1598-1600.

Pörtner, H.-O., 2010. Oxygen- and capacity-limitation of thermal tolerance: a matrix for integrating climate-related stressor effects in marine ecosystems. J. Exp. Biol. 213: 881-893. http://dx.doi.org/10.1242/jeb.037523.

Pörtner, H.O., Bennett, A.F., Bozinovic, F., Clarke, A., Lardies, M.A., Lucassen, M., Pelster, B Schiemer, F., Stillman, J.H., 2006. Trade-offs in thermal adaptation: the need for a molecular to ecological integration. Physiol. Biochem. Zool. Ecol. Evol. Approaches 79: 295-313. http://dx.doi.org/10.1086/499986.

Rahman, I., Kode, A., Biswas, S.K., 2007. Assay for quantitative determination of glutathione and glutathione disulfide levels using enzymatic recycling method. Nat. Protoc 1:3159-3165. http://dx.doi.org/10.1038/nprot.2006.378.

Reece, K.S., Cordes, J.F., Stubbs, J.B., Hudson, K.L., Francis, E.A., 2008. Molecular phylogenies help resolve taxonomic confusion with Asian Crassostrea oyster species. Mar. Biol. 153, 709-721.

Regoli, F., Giuliani, M.E., 2014. Oxidative pathways of chemical toxicity and oxidative stress biomarkers in marine organisms. Mar. Environ. Res. 93, 106-117.

Ristori, C.A., Iaria, S.T., Gelli, D.S., Rivera, I.N.G., 2007. Pathogenic bacteria associated with oysters (Crassostrea brasiliana) and estuarine water along the south coast of Brazil. Int J. Environ. Health Res. 17:259-269. http://dx.doi.org/10.1080/09603120701372169.

Rivera-Ingraham, G.A., Rocchetta, I., Meyer, S., Abele, D., 2013. Oxygen radical formation in anoxic transgression and anoxia-reoxygenation: foe or phantom? Experiments with a hypoxia tolerant bivalve. Mar. Environ. Res. 92:110-119. http://dx.doi.org/ 10.1016/j.marenvres.2013.09.007.

Robinson, H.W., Hogden, C.G., 1940. The biuret reaction in the determination of serum proteins. 1. A study of the conditions necessary for the production of a stable color which bears a quantitative relationship to the protein concentration. J. Biol. Chem. 135, 707-725.

Robertson, A.I., Phillips, M.J., 1995. Mangroves as filters of shrimp pond effluent: predictions and biogeochemical research needs. Hydrobiologia 295:311-321. http://dx. doi.org/10.1007/BF00029138.

Ruesink, J.L., Lenihan, H.S., Trimble, A.C., Heiman, K.W., Micheli, F., Byers, J.E., Kay, M.C., 2005. Introduction of non-native oysters: ecosystem effects and restoration implications. Annu. Rev. Ecol. Evol. Syst. 36:643-689. http://dx.doi.org/10.1146/annurev. ecolsys.36.102003.152638.

Sappal, R., MacDougald, M., Fast, M., Stevens, D., Kibenge, F., Siah, A., Kamunde, C., 2015 Alterations in mitochondrial electron transport system activity in response to warm acclimation, hypoxia-reoxygenation and copper in rainbow trout, Oncorhynchus mykiss. Aquat. Toxicol. 165:51-63. http://dx.doi.org/10.1016/j.aquatox.2015.05.014.

Schaeffer-Novelli, Y., Mesquita, H.d.S.L., Cintrón-Molero, G., 1990. The Cananéia Lagoon estuarine system, São Paulo, Brazil. Estuaries 13:193-203. http://dx.doi.org/10 2307/1351589.

Simčič, T., Brancelj, A., 2004. Respiratory electron transport system (ETS) activity as an estimator of the thermal tolerance of two Daphnia hybrids. J. Plankton Res. 26:525-534 http://dx.doi.org/10.1093/plankt/fbh056.

Simčič, T., Lukančič, S., Brancelj, A., 2005. Comparative study of electron transport system activity and oxygen consumption of amphipods from caves and surface habitats Freshw. Biol. 50:494-501. http://dx.doi.org/10.1111/j.1365-2427.2005.01339.x.

Simčič, T., Pajk, F., Jaklič, M., Brancelj, A., Vrezec, A., 2014. The thermal tolerance of crayfish could be estimated from respiratory electron transport system activity. J. Therm. Biol. 41:21-30. http://dx.doi.org/10.1016/j.jtherbio.2013.06.003.

Smith, J.B., Schneider, S.H., Oppenheimer, M., Yohe, G.W., Hare, W., Mastrandrea, M.D., Patwardhan, A., Burton, I., Corfee-Morlot, J., Magadza, C.H.D., Füssel, H.-M., Pittock, A.B., Rahman, A., Suarez, A., van Ypersele, J.-P., 2009. Assessing dangerous climate change through an update of the Intergovernmental Panel on Climate Change (IPCC) “reasons for concern". Proc. Natl. Acad. Sci. 106:4133-4137. http://dx.doi. org/10.1073/pnas.0812355106.

Smolders, R., Bervoets, L., De Coen, W., Blust, R., 2004. Cellular energy allocation in zebra mussels exposed along a pollution gradient: linking cellular effects to higher levels of biological organization. Environ. Pollut. 129:99-112. http://dx.doi.org/10.1016/j. envpol.2003.09.027.

Sokolova, I.M., Lannig, G., 2008. Interactive effects of metal pollution and temperature on metabolism in aquatic ectotherms: implications of global climate change. Clim. Res. 37, 181-201

Sokolova, I.M., Frederich, M., Bagwe, R., Lannig, G., Sukhotin, A.A., 2012. Energy homeostasis as an integrative tool for assessing limits of environmental stress tolerance in aquatic invertebrates. Mar. Environ. Res. 79:1-15. http://dx.doi.org/10.1016/j. marenvres.2012.04.003.

Solomon, S., 2007. Climate Change 2007-The Physical Science Basis: Working Group I Contribution to the Fourth Assessment Report of the IPCC. Cambridge University Press.

Somero, G.N., 2010. The physiology of climate change: how potentials for acclimatization and genetic adaptation will determine "winners" and "losers". J. Exp. Biol. 213: 912-920. http://dx.doi.org/10.1242/jeb.037473.

Somero, G.N., 2012. The physiology of global change: linking patterns to mechanisms. Annu. Rev. Mar. Sci. 4:39-61. http://dx.doi.org/10.1146/annurev-marine-120710100935.

Storey, K.B., 1998. Survival under stress: molecular mechanisms of metabolic rate depression in animals. S. Afr. J. Zool. 33, 55-64.

Sukhotin, A.A., Pörtner, H.-O., 2001. Age-dependence of metabolism in mussels Mytilus edulis (L.) from the White Sea. J. Exp. Mar. Biol. Ecol. 257:53-72. http://dx.doi.org/ 10.1016/S0022-0981(00)00325-7.

Sukhotin, A.A., Abele, D., Pörtner, H.O., 2002. Growth, metabolism and lipid peroxidation in Mytilus edulis L.: age and size effects. Mar. Ecol.-Prog. Ser. 226, 223-234.

Talmage, S.C., Gobler, C.J., 2011. Effects of elevated temperature and carbon dioxide on the growth and survival of larvae and juveniles of three species of Northwest Atlantic bivalves. PLoS One 6. http://dx.doi.org/10.1371/journal.pone.0026941.

Tamura, K., Stecher, G., Peterson, D., Filipski, A., Kumar, S., 2013. MEGA6: molecular evolutionary genetics analysis version 6.0. Mol. Biol. Evol. 30, 2725-2729.

Tomanek, L., 2014. Proteomics to study adaptations in marine organisms to environmental stress. J. Proteomics, Spec. Issue: Proteomics Non-Model Org. 105:92-106. http:// dx.doi.org/10.1016/j.jprot.2014.04.009.

Tomanek, L., Zuzow, M.J., 2010. The proteomic response of the mussel congeners Mytilus galloprovincialis and $M$. trossulus to acute heat stress: implications for thermal tolerance limits and metabolic costs of thermal stress. J. Exp. Biol. 213:3559-3574. http://dx.doi.org/10.1242/jeb.041228.

Velez, C., Teixeira, M., Wrona, F.J., Soares, A.M.V.M., Figueira, E., Freitas, R., 2016. Clam Ruditapes philippinarum recovery from short-term exposure to the combined effect of salinity shifts and arsenic contamination. Aquat. Toxicol. Amst. Neth. 173: 154-164. http://dx.doi.org/10.1016/j.aquatox.2016.01.007.

Verlecar, X.N., Jena, K.B., Chainy, G.B.N., 2007. Biochemical markers of oxidative stress in Perna viridis exposed to mercury and temperature. Chem. Biol. Interact. 167: 219-226. http://dx.doi.org/10.1016/j.cbi.2007.01.018.

Viarengo, A., Canesi, L., Pertica, M., Livingstone, D.R., Orunesu, M., 1991. Age-related lipid peroxidation in the digestive gland of mussels: the role of the antioxidant defence systems. Experientia 47:454-457. http://dx.doi.org/10.1007/BF01959942.

Vladimirova, I.G., Kleimenov, S.Y., Radzinskaya, L.I., 2003. The relation of energy metabolism and body weight in bivalves (Mollusca: Bivalvia). Biol. Bull. Russ. Acad. Sci. 30: 392-399. http://dx.doi.org/10.1023/A:1024822225406.

Yoshikawa, H., 1959. Glycogen. Rinsho Ikagaku Kyodoisho Tokyo 150-152.

Yurista, P.M., 1999. A model for temperature correction of size-specific respiration in Bythotrephes cederstroemi and Daphnia middendorffiana. J. Plankton Res. 21, 721-734.

Zanette, J., Monserrat, J.M., Bianchini, A., 2006. Biochemical biomarkers in gills of mangrove oyster Crassostrea rhizophorae from three Brazilian estuaries. Comp. Biochem. Physiol. Toxicol. Pharmacol. 143:187-195. http://dx.doi.org/10.1016/j.cbpc.2006.02.001. 